\title{
MULTIFUNGSI PERTANIAN PADI SAWAH DI KABUPATEN POSO
}

\author{
The Multifunctionality of Paddy Field Agriculture At Poso Regency \\ Marianne Reynelda Mamondol \\ Fakultas Pertanian Universitas Kristen Tentena \\ Jln. Torulemba No. 21 Tentena, Poso, Sulawesi Tengah \\ e-mail: mariannemamondol@gmail.com
}

\begin{abstract}
Abstrak
Peran strategis komoditas padi di Kabupaten Poso saat ini menghadapi tantangan yang cukup serius, di antaranya berupa masalah konversi lahan pertanian sebagai konsekuensi dari pembangunan ekonomi daerah yang cukup pesat. Konversi lahan terkait dengan kenyataan bahwa masyarakat di Kabupaten Poso, termasuk petani, belum pertanian mengetahui dan memahami konsep nilai ekonomi dan keberlanjutan lahan pertanian padi sawah dan konsep multifungsi yang dimilikinya. Lahan sawah dianggap semata-mata hanya sebagai penghasil produk pangan berupa beras yang terlihat secara nyata (tangible) dan dapat dipasarkan (marketable), sedangkan berbagai fungsi lainnya yang menyangkut aspek-aspek lingkungan, sosial, dan budaya tidak banyak diketahui bahkan cenderung diabaikan. Selain sebagai penyedia produk beras sebagai bahan pangan pokok masyarakat, pertanian padi sawah di Kabupaten Poso memiliki fungsi-fungsi lain seperti mengurangi risiko banjir di daerah hilir, mengendalikan erosi dan pendangkalan badan air, memelihara sumberdaya air, memperbaiki iklim lokal, mengurangi penumpukan sampah organik, menjadi habitat flora dan fauna, memelihara nilai-nilai sosial budaya dan daya tarik pedesaan, menyediakan lapangan pekerjaan, dan menyangga ketahanan pangan keluarga dan daerah. Terdapat beberapa metode valuasi untuk mengkuantifikasikan nilai dari fungsi-fungsi tersebut. Valuasi multifungsi pertanian mengindikasikan bahwa lahan sawah memiliki nilai ekonomi riil yang jauh lebih besar daripada perhitungan nilai ekonomi secara konvensional, sehingga lahan sawah memberikan kontribusi ekonomi, sosial, budaya, dan lingkungan hidup bagi masyarakat.
\end{abstract}

Kata Kunci : multifungsi pertanian, padi sawah, Kabupaten Poso

\begin{abstract}
Recently the strategic roles of paddy commodity at Poso Regency deal with serious challenges, one of them is the problem of agricultural land conversion as the consequences of rapid regional economic development. Land conversion associates with the fact that many people have not yet known and realized the concepts of economic value and the sustainability of paddy fields as well as the multifunctionality concept. Paddy fields are only considered as the tangible and marketable food products in the form of rice, whereas the another functions which relate to the aspects of environmental, social, and cultural are not much familiar even tend to be denied. Besides the producer of rice product, paddy field agriculture has another functions as to reduce the risk of flood downstream, to control erosion and sedimentation of waterways, to preserve water resources, to improve local climate, to decrease the accumulation of organic wastes, to become the habitat of flora and fauna, to maintain social and cultural values as well as rural attraction, to provide work field, and to support household and regional food security. There are some valuation methods to quantify the values of those functions. The valuation of agriculture multifunctionality indicates that paddy field has real economic value which is higher than that of conventional accounting results, so that paddy fields contributes to society economically, socially, culturally, and environmentally.
\end{abstract}

Keywords : agriculture multifunctionality, paddy field, Poso Regency 


\section{PENDAHULUAN}

Kabupaten Poso termasuk kawasan yang potensial untuk pengembangan sektor pertanian Provinsi Sulawesi Tengah. Hal ini dimungkinkan karena dukungan ketersediaan sumberdaya alam berupa lahan, air, dan agroklimat serta sumberdaya manusia berupa tenaga kerja petani. Ditinjau dari sisi pembangunan ekonomi daerah, sumbangan sektor pertanian selama kurun waktu tahun 2009 hingga 2012 cukup besar. Kontribusi sektor pertanian terhadap Produk Domestik Regional Bruto (PDRB) Kabupaten Poso pada kurun waktu tersebut rata-rata mencapai $49,40 \%$ (BPS Poso, 2014).

Salah satu sub sektor yang turut berperan dalam pencapaian tersebut ialah sub sektor tanaman pangan, termasuk di dalamnya komoditas padi sawah. Padi sawah merupakan komoditas tanaman yang bernilai strategis. Produk beras yang dihasilkannya bukan saja merupakan bahan pangan pokok penduduk tetapi juga merupakan produk yang memiliki sensitivitas politik, ekonomi, dan sosial yang cukup tinggi. Ketergantungan penduduk yang begitu besar pada beras menyebabkan apabila terjadi sedikit gangguan terhadap produksi beras akan menimbulkan pula gangguan pada pasokan beras sehingga berakibat pada melonjaknya harga jual beras.

Peran strategis komoditas padi di Kabupaten Poso saat ini menghadapi lahan bersifat dilematis. Peningkatan jumlah penduduk dan pertumbuhan kegiatan ekonomi merupakan aktivitas yang sangat memerlukan lahan. Di sisi lain, pertambahan tantangan yang cukup serius, di antaranya berupa masalah konversi lahan pertanian, terutama lahan sawah tadah hujan serta lahan sawah produktif. Menurut Harini (2012), konversi lahan sebenarnya merupakan gejala yang normal dalam kaitannya dengan perkembangan suatu daerah. Tetapi pada kenyataannya, konversi jumlah penduduk memerlukan persediaan bahan pangan dalam jumlah besar, sehingga memerlukan lahan pertanian yang luas. Padahal lahan pertanian merupakan sumberdaya yang terbatas jumlahnya. Kondisi demikian menyebabkan persaingan ketat dalam pemanfaatan lahan, sehingga berakibat pada meningkatnya nilai lahan (land rent).

Di beberapa kecamatan pada wilayah Kabupaten Poso, konversi lahan sawah menjadi lokasi perumahan, perkantoran, atau pertokoan merupakan konsekuensi dari pembangunan ekonomi daerah yang cukup pesat pasca konflik sosial yang terjadi di akhir tahun 1990-an hingga awal tahun 2000-an. Penelitian yang dilakukan oleh Tobade (2012) memperlihatkan bahwa konversi lahan sawah di Kecamatan Pamona Timur disebabkan oleh beberapa faktor seperti degradasi kesuburan lahan sawah, berkurangnya pasokan air, terjadinya serangan hama dan penyakit tanaman padi yang tidak mampu diatasi petani, serta daya tarik komoditas pertanian non padi sawah dan sektor non pertanian yang lebih menguntungkan secara ekonomis.

Hasil survei pendahuluan juga menunjukkan bahwa masyarakat di Kabupaten Poso, termasuk petani, belum mengetahui dan memahami konsep nilai ekonomi dan keberlanjutan lahan pertanian, secara khusus padi sawah. Pola penanaman padi sawah di sebagian besar pedesaan umumnya tidak berkesinambungan karena keterbatasan modal kerja dan ketergantungan petani terhadap musim penghujan untuk memulaikan setiap kegiatan penanaman. Hal ini dapat dipahami karena sebagian besar lahan sawah yang diusahakan petani merupakan sawah tadah hujan. Fakta lainnya ialah bahwa tata kelola sumber air yang ada di sekitar pedesaan serta pergiliran tanam padi dengan komoditas palawija atau sayur-sayuran juga masih sangat minim dilakukan oleh petani. Sebaliknya, pemberian pupuk kimia dalam dosis besar dan jangka waktu lama, drainase tanah sawah yang buruk, dan tidak pernah dilakukannya penambahan bahan organik ke dalam tanah justru merupakan praktik-praktik yang banyak dijumpai di kalangan petani. Padahal menurut Soemarno (2010), intensifikasi padi dengan asupan pupuk kimia dalam jumlah besar dan dalam jangka waktu lama, tiadanya rotasi tanaman, buruknya drainase, serta kurangnya memperhatikan penggunaan bahan organik akan mengakibatkan terganggunya keseimbangan hara tanah yang berakibat pada penurunan kualitas sumberdaya lahan sawah.

Fenomena yang telah diuraikan menunjukkan rendahnya penghargaan masyarakat dan pemerintah terhadap keberadaan lahan sawah. Lahan sawah dianggap semata-mata hanya sebagai penghasil produk pangan berupa beras yang 
terlihat secara nyata (tangible) dan dapat dipasarkan (marketable). Sementara itu, berbagai fungsi lahan sawah lainnya seperti terhadap aspek-aspek lingkungan, ekonomi, sosial, dan budaya tidak banyak diketahui, atau kalau pun diketahui cenderung diabaikan.

Sistem pasar yang ada menganggap bahwa fungsi-fungsi lain dari lahan sawah tersebut merupakan eksternalitas, yaitu elemen dalam sistem produksi yang belum bahkan tidak diperhitungkan biaya dan manfaatnya. Harga pasar gagal memasukkan biaya sebagai dampak adanya eksternalitas terhadap masyarakat (Rahardja dan Manurung, 2006). Di sisi lain, kebijakan pemerintah di bidang pertanian, baik di tingkat pusat maupun daerah, lebih banyak terfokus pada keuntungan ekonomi jangka pendek. Sistem pasar dan kebijakan pemerintah yang menganggap jasa yang dihasilkan pertanian sebagai eksternalitas telah menyebabkan semakin rendahnya insentif untuk bertani.

Selain merupakan ancaman terhadap ketahanan pangan daerah, masalah konversi lahan sawah menimbulkan konsekuensi berupa bahaya yang dapat mengancam kehidupan manusia. Terdapat indikasi bahwa meningkatnya bencana alam seperti banjir, erosi, dan kemarau panjang erat kaitannya dengan konversi lahan pertanian yang berakibat hilangnya sebagian dari fungsi lahan berupa konservasi sumberdaya air, mitigasi banjir, dan pengendali erosi.

Pertanian padi sawah memiliki jasa yang bersifat multifungsi, yaitu sebagai penghasil bahan pangan berupa beras, serta fungsi-fungsi lainnya dalam menjaga kualitas lingkungan (mitigasi banjir, pengendali erosi, konservasi sumberdaya air, mitigasi gas rumah kaca, pelestari keanekaragaman hayati, pendaur ulang limbah organik), menyangga ketahanan pangan, menyediakan lapangan pekerjaan di pedesaan, memelihara sistem budaya dan sosial pedesaan, dan menciptakan keindahan panorama alam pedesaan (Mukhoriyah, 2012). Sebagai contoh, untuk sistem padi sawah yang ada di Daerah Aliran Sungai (DAS) Citarum, jasa lingkungan yang diberikannya bernilai sekitar $51 \%$ dari nilai beras yang dihasilkan, berupa mitigasi banjir, penanggulangan erosi, pendaur ulang limbah organik, pendaur ulang air, dan fungsi pariwisata (Hanafie, 2010). Beberapa penelitian tentang identifikasi dan penilaian multifungsi pertanian telah dilakukan, di antaranya oleh Prihtanti $d k k$ (2013) yang menganalisis 8 fungsi pertanian padi sawah organik dan non organik di Kabupaten Karanganyar dan Sragen, Jawa Tengah.

Penelitian ini bertujuan untuk melakukan identifikasi terhadap multifungsi pertanian padi sawah di Kabupaten Poso beserta teknikteknik kuantitatif yang dapat digunakan untuk mengukur setiap fungsi.

\section{METODE PENELITIAN}

Penelitian ini dilaksanakan di Kabupaten Poso Provinsi Sulawesi Tengah pada bulan Februari hingga Mei 2015. Pengumpulan data dilakukan dengan wawancara pada beberapa subyek penelitian yang dipilih secara sengaja, dengan pertimbangan bahwa subyek penelitian memiliki kelengkapan informasi sesuai kebutuhan peneliti. Subyek penelitian dalam hal ini ialah petani padi sawah dan Petugas Penyuluh Lapangan (PPL) di Kabupaten Poso Provinsi Sulawesi Tengah. Selain itu juga dilakukan studi literatur untuk mengumpulkan data dari berbagai sumber yang terkait dengan penelitian ini. Data-data penelitian selanjutnya dianalisis secara kualitatif deskriptif di mana informasi atau keterangan yang diperoleh diuraikan secara terperinci guna memberikan penjelasan dan pemahaman terhadap topik penelitian.

\section{HASIL DAN PEMBAHASAN}

\section{Konsep Multifungsi Pertanian}

Pertanian merupakan usaha yang berbasiskan penggunaan sumberdaya alam yang meliputi tanah, air, dan genetika. Apabila tidak dikelola dengan bijaksana, maka eksploitasi terhadap sumberdaya-sumberdaya tersebut akan merusakkan kapasitasnya yang selanjutnya akan menurunkan pula potensi produktivitasnya. Penurunan potensi produktivitas sumberdaya dapat menyebabkan produktivitas usaha pertanian secara keseluruhan akan menurun sehingga daya saing usaha pertanian akan mengalami penurunan pula. Apabila hal ini terjadi maka usaha pertanian tidak dapat bertahan secara berkelanjutan (Hanafie, 2010).

Ancaman terhadap keberlanjutan usaha pertanian di Indonesia saat ini merupakan fenomena yang kian memprihatinkan. Ini 
dapat dilihat dari beberapa indikator berupa : 1) menurunnya minat generasi muda untuk bekerja di sektor pertanian karena lebih tertarik bekerja di sektor industri dan jasa yang memberikan pendapatan yang jauh lebih besar,

2) semakin sunyinya daerah pedesaan karena ditinggalkan oleh kaum muda yang mencari pekerjaan di sektor industri dan jasa di daerah perkotaan, dan 3) meningkatnya konversi lahan pertanian ke aktivitas-aktivitas nonpertanian, di antaranya ialah konversi lahan sawah (Balai Penelitian Tanah, 2006). Arifin (2007) menyebutkan bahwa laju konversi lahan sawah, termasuk lahan sawah produktif di Indonesia telah mencapai angka 141 ribu hektar per tahun.

Menurut Fauzi (2006), hal demikian terjadi karena pada umumnya setiap orang secara eksplisit memperlakukan seluruh barang dan jasa yang dihasilkan dari sumberdaya alam dan lingkungan sebagai sesuatu yang dapat dinilai secara moneter. Dengan kata lain, barang dan jasa yang dihasilkan tersebut bisa dihitung nilai ekonominya karena diasumsikan bahwa pasar bersifat eksis (market based), sehingga transaksi barang dari sumberdaya alam tersebut dapat dilakukan. Padahal, sumberdaya alam, selain menghasilkan barang dan jasa yang dapat dikonsumsi baik langsung maupun tidak langsung, juga menghasilkan jasa-jasa (services) lingkungan yang memberikan manfaat dalam bentuk lain, misalnya manfaat kenyamanan (amenity), keindahan dan ketenangan. Manfaat seperti ini sering lebih terasa dalam jangka panjang. Manfaat lahan sawah sebagai kawasan konservasi biodiversitas, misalnya, baru disadari justru setelah orang tidak lagi dapat menikmati keanekaragaman hayati yang hilang karena menghilangnya lahan sawah. Manfaat-manfaat fungsi ekologis tersebut (ecological function) sering tidak terkuantifikasikan dalam perhitungan menyeluruh terhadap nilai dari sumberdaya. Mengingat pentingnya fungsi-fungsi ekonomi dan non ekonomi dari sumberdaya alam, tantangan yang dihadapi oleh penentu kebijakan adalah bagaimana memberikan nilai yang komprehensif terhadap sumberdaya alam itu sendiri. Dalam hal ini, nilai tersebut tidak saja merupakan nilai pasar (market value) yang bersifat kelihatan (tangible), tetapi juga nilai non pasar (non marketable value) yang tidak kelihatan (intangible).

Balai Penelitian Tanah (2006) mendefinisikan multifungsi pertanian sebagai konsep yang menjabarkan berbagai fungsi eksternal pertanian bagi lingkungan, ketahanan pangan, ekonomi, sosial, dan budaya. Sebagai penyedia jasa yang tidak nyata (intangible) dan tidak dapat dipasarkan (non-marketable), sesungguhnya multifungsi pertanian selama ini telah dinikmati oleh masyarakat luas, hanya saja sering tidak disadari. Dari sisi petani sebagai konstituen terbesar pertanian Indonesia, multifungsi pertanian merupakan kontribusi cuma-cuma yang diberikan oleh petani kepada masyarakat. Hal ini disebabkan karena karakteristik multifungsi pertanian ialah berupa barang publik hasil ikutan suatu proses produksi. Karena bersifat barang publik, maka multifungsi pertanian bisa dinikmati oleh siapa saja secara gratis.

De Vries (2000) dalam Prihtanti $d k k$ (2013) menyatakan bahwa praktik pertanian selalu memiliki peran dan fungsi yang saling terkait satu sama lain, baik antara aspek ekonomi, lingkungan maupun sosial. Dengan demikian multifungsi pertanian merupakan konsep keterkaitan peran dan fungsi sektor pertanian dalam sebuah sistem yang terintegrasi. Paradigma ini dapat diimplementasikan dalam pembangunan pertanian pedesaan yang berupaya mengeksplorasi fungsi pasar dan non pasar praktik pertanian.

\section{Multifungsi Pertanian Padi Sawah di Kabupaten Poso}

Selain sebagai penghasil beras yang merupakan bahan pangan pokok masyarakat, multifungsi pertanian padi sawah di Kabupaten Poso berdasarkan hasil penelitian ialah sebagai berikut :

\section{1) Mengurangi risiko banjir di daerah hilir}

Menurut Agus dan Husen (2005), kemampuan lahan menahan air merupakan indikator fungsi mitigasi banjir. Lahan pertanian dapat menahan sebagian air hujan di dalam tanaman (air genangan) dan di dalam pori tanah. Kemampuan menahan air lahan sawah setara dengan sistem pertanian berbasis pohonpohonan meskipun lebih rendah daripada hutan. Petakan sawah berfungsi sebagai 
kolam-kolam penampung air selama dan sesaat sesudah hujan sehingga mengurangi pasokan air ke sungai. Kemampuan menahan air sistem pertanian berbasis tanaman semusim (tegalan) jauh lebih rendah daripada sawah, tetapi sistem ini masih jauh lebih baik daripada areal pemukiman dan industri. Karena itu, konversi lahan pertanian ke areal pemukiman dan industri berpotensi meningkatkan frekuensi dan intensitas banjir di daerah hilir.

\section{2) Mengendalikan erosi dan pendangkalan badan air}

Sistem pertanian multistrata, yaitu sawah dengan pematang dan teras-teras, dan lahan yang dikonservasi dengan baik, mampu mengendalikan erosi dan penghanyutan senyawa kimia ke daerah hilir. Tajuk tanaman yang berlapis pada sistem pertanian multistrata menurunkan energi kinetik curah hujan sehingga berperan sebagai pengendali erosi yang baik. Teras sawah dan pematang berfungsi menahan air dan mengendapkan partikel-partikel tanah beserta unsur-unsur hara yang hanyut dari daerah hulu, sehingga mencegah pendangkalan badan air seperti danau. Erosi tanah dari hamparan sawah sama rendahnya dengan erosi pada hutan primer. Apabila lahan pertanian dikonversi ke aktivitas non pertanian maka kemampuan daerah ini menahan air akan menurun dan aliran permukaan meningkat, yang selanjutnya mempercepat erosi dan sedimentasi (Sutrisno $d k k, 2012)$.

\section{3) Memelihara sumberdaya air}

Pada lahan persawahan, sebagian air irigasi dan air hujan akan masuk ke tanah sebagai air perkolasi. Sekitar $25 \%$ dari air perkolasi akan mengisi air tanah dan sisanya akan mengalir ke sungai dan waduk. Air ini dapat kembali dimanfaatkan untuk berbagai tujuan dan kepentingan (Agus $d k k, 2004$ ).

\section{4) Memperbaiki iklim lokal}

Irawan $d k k$ (2006) menyatakan bahwa pelepasan gas rumah kaca dari berbagai pabrik atau industri dan kendaraan bermotor menimbulkan udara panas dan tidak nyaman. Penguapan air, baik dari genangan air sawah maupun dari tajuk tanaman menurunkan suhu udara. Fotosintesis tanaman selain menyerap panas juga menghasilkan oksigen yang memberikan efek segar bagi lingkungan di sekitarnya. Pada saat yang bersamaan, tanaman mampu membersihkan polutan di udara seperti gas-gas $\mathrm{SO}_{2}$ dan $\mathrm{NO}_{2}$.

\section{5) Mengurangi penumpukan sampah organik}

Penumpukan sampah telah menjadi masalah yang cukup pelik di kawasan perumahan dan perkotaan. Berbagai jenis mikroba perombak bahan organik di dalam tanah ternyata mampu mengurai sampah menjadi zat-zat hara yang dibutuhkan tanaman. Di beberapa daerah, sampah telah diproses menjadi kompos dan digunakan sebagai pupuk organik. Walaupun demikian, perlu dilakukan pengujian mutu kompos untuk memastikan bahwa kompos tidak mengandung logam berat dan senyawa beracun lainnya demi keamanan penggunaan kompos bagi tanaman pangan. Sumbangan sektor pertanian, termasuk pertanian padi sawah sebagai penyerap sampah organik dapat ditingkatkan jika masyarakat sudah terdidik dan terbiasa memisahkan sampah organik yang dapat lapuk dari yang sulit lapuk (seperti plastik dan kaleng) sehingga proses pengomposan menjadi lebih mudah (Balai Penelitian Tanah, 2006).

\section{6) Menjadi habitat flora dan fauna}

Sistem pertanian padi sawah menyediakan beraneka jenis makanan bagi burung, hewan menyusui, serangga, binatang kecil, dan mikroorganisme (Liu $d k k, 2013$ ). Konservasi sumberdaya hayati ini penting dalam bidang medis dan ilmu pengetahuan, dan juga untuk berlangsungnya berbagai proses biokimia dan keseimbangan alami. Pada ekosistem persawahan di Kabupaten Poso terdapat beberapa jenis hewan seperti burung bangau putih, keong emas, dan katak sawah yang menjadi biota khas lahan sawah.

\section{7) Memelihara nilai sosial budaya dan daya tarik pedesaan}

Nilai-nilai sosial budaya dan tradisi masyarakat pedesaan melekat pada sistem pertanian dan merupakan ciri khas kehidupan pedesaan di Indonesia. Nilai-nilai sosial dan budaya ini tercermin pada sikap kegotongroyongan dan kebersamaan dalam kelompok tani termasuk keberadaan kelompok tani wanita. Pada sistem pertanian padi sawah di Kabupaten Poso berkembang tradisi mesale atau pola kerja sama kelompok pada saat penanaman dan panen padi di mana tenaga kerja yang bekerja pada lahan sawah milik petani tertentu dibayar dengan uang atau dengan natura. Setiap tahun, pada akhir musim panen raya padi sawah, di Kabupaten Poso diadakan pesta padungku atau 
pengucapan syukur oleh masyarakat atas keberhasilan panen dan perayaan tersebut dilaksanakan secara meriah di desa-desa. Nilai-nilai sosial dan budaya ini, ditambah dengan panorama alam pedesaan yang indah dapat menciptakan daya tarik tersendiri bagi masyarakat perkotaan untuk melakukan wisata ke kawasan pedesaan.

\section{8) Menyediakan lapangan pekerjaan}

Sektor pertanian padi sawah mempekerjakan sekitar 50,03 \% angkatan kerja di Kabupaten Poso (BPS, 2015). Meskipun saat ini pekerjaan bertani kurang diminati generasi muda Indonesia, pertanian tetap berperan sebagai jaring pengaman bagi para pencari kerja. Tantangan ke depan yang perlu dipikirkan ialah bagaimana membuat pertanian menjadi suatu usaha yang menarik bagi generasi muda. Pemberian imbalan atau penghargaan bagi petani yang telah menyediakan berbagai jasa (multifungsi) pertanian perlu diupayakan atau ditingkatkan untuk meminimalkan kendala yang banyak dijumpai dalam usahatani.

\section{9) Menyangga ketahanan pangan keluarga dan daerah}

Ketahanan pangan menurut FAO (1997) dalam Hanafie (2010) adalah situasi di mana semua rumah tangga mempunyai akses, baik secara fisik maupun ekonomi untuk memperoleh pangan bagi seluruh anggota keluarganya dan rumah tangga tidak berisiko untuk mengalami kehilangan kedua akses tersebut. Jadi, determinan utama dari ketahanan pangan ialah daya beli atau pendapatan yang memadai untuk memenuhi biaya konsumsi pangan. Ketahanan pangan rumah tangga merupakan penentu ketahanan pangan daerah, sebab jika dalam skala mikro, seperti rumah tangga, akses untuk memperoleh pangan terjamin, maka ini akan menunjukkan aksesibilitas yang baik pula pada tingkat makro. Sistem pertanian padi sawah, apakah itu bersifat subsisten maupun komersil, dapat memberikan jaminan akses bagi setiap individu dalam rumah tangga maupun daerah untuk menikmati pemenuhan kebutuhan pangan, dalam hal ini bahan kebutuhan pangan pokok berupa beras.

Hasil wawancara menunjukkan bahwa motivasi sebagian besar petani untuk menanam padi ialah untuk memenuhi kebutuhan beras rumah tangga agar rumah tangga petani tidak perlu lagi mengalokasikan uang untuk berbelanja beras di pasar. Hal ini dapat dipandang sebagai upaya petani untuk menjamin aksesibilitas dirinya dan keluarganya terhadap beras sebagai kebutuhan pangan pokok dalam keluarga.

\section{Metode Valuasi Multifungsi Pertanian Padi Sawah \\ Multifungsi pertanian padi sawah dapat diukur dengan beberapa metode valuasi sebagai berikut :}

1) Fungsi lahan sawah dalam mengurangi risiko banjir di daerah hilir

Nilai lahan sawah dalam mengurangi risiko banjir didasarkan pada perhitungan biaya pengganti (replacement cost) berupa pembangunan bandungan yang berfungsi sebagai pengatur air (Agus $d k k, 2004$ ). Jika diasumsikan lahan sawah mengalami konversi ke penggunaan lainnya seperti perumahan atau pembuatan kawasan industri, maka biaya pengganti untuk mitigasi banjir dinyatakan dalam rumus : $\mathrm{RC}_{\mathrm{F}}=\left(\mathrm{Pi}_{\mathrm{pf}}-\mathrm{P}_{\mathrm{ui}}\right) * \mathrm{~A} * \mathrm{CR} *\left(\mathrm{D}_{\mathrm{c}}+\mathrm{M}_{\mathrm{c}}\right)$ Keterangan :

\begin{tabular}{|c|c|}
\hline $\mathrm{RC}_{\mathrm{F}}$ & $\begin{aligned}= & \text { Nilai fungsi lahan sawah } \\
& \text { untuk mitigasi banjir } \\
& \left(\text { Rp tahun }{ }^{-1}\right)\end{aligned}$ \\
\hline $\mathrm{Pi}_{\mathrm{pf}}$ & $\begin{aligned}= & \text { Kapasitas menahan air dari } \\
& \text { tanaman padi sawah }(\mathrm{m})\end{aligned}$ \\
\hline $\mathrm{P}_{\mathrm{ui}}$ & $\begin{aligned}= & \text { Kapasitas menahan air dari } \\
& \text { areal perkotaan dan } \\
& \text { industri }(\mathrm{m})\end{aligned}$ \\
\hline A & $\begin{aligned}= & \text { Luas areal pertanaman padi } \\
& \text { sawah }\left(\mathrm{m}^{2}\right)\end{aligned}$ \\
\hline CR & $\begin{aligned}= & \text { Nilai konversi lahan pada } \\
& 2 \text { dekade berikut, yang } \\
& \text { diasumsikan sebesar } 0,3\end{aligned}$ \\
\hline $\mathrm{D}_{\mathrm{c}}$ & $\begin{aligned} &= \text { Biaya penyusutan } \\
& \text { bendungan dari setiap unit } \\
& \text { air yang tersimpan } \\
&\left(\mathrm{Rp} \mathrm{m}^{-3} \text { tahun }^{-1}\right)\end{aligned}$ \\
\hline $\mathrm{M}_{\mathrm{c}}$ & $\begin{aligned}= & \text { Biaya pemeliharaan } \\
& \text { bendungan dari setiap unit } \\
& \text { air yang tersimpan } \\
& \left(\mathrm{Rp} \mathrm{m}^{-3} \text { tahun }^{-1}\right)\end{aligned}$ \\
\hline
\end{tabular}

2) Fungsi lahan sawah dalam mengendalikan erosi dan pendangkalan badan air Apabila lahan sawah dikonversi menjadi kawasan perumahan dan industri, maka permukaan tanah akan lebih bersifat impermiabel sehingga meningkatkan aliran permukaan dan laju erosi. 
Hilangnya fungsi lahan sawah untuk mitigasi erosi dan sedimentasi dinyatakan pada perhitungan biaya pengganti berupa pembangunan bendungan untuk menyaring dan mengakumulasi sedimen (Sutrisno $d k k, 2012)$, dan dinyatakan dalam rumus :

$$
\begin{aligned}
\mathrm{RC}_{\mathrm{E}}= & \left(\mathrm{E}_{\mathrm{u}}-\mathrm{E}_{\mathrm{pf}}\right) * \mathrm{~A} * \mathrm{CR} * \mathrm{SDR} * \\
& \left(\mathrm{D}_{\mathrm{c}}+\mathrm{M}_{\mathrm{c}}\right)
\end{aligned}
$$

Keterangan :

$$
\begin{aligned}
& \mathrm{RC}_{\mathrm{E}} \quad=\text { Nilai fungsi lahan sawah } \\
& \text { untuk mitigasi erosi dan } \\
& \text { sedimentasi (Rp tahun } \left.{ }^{-1}\right) \\
& \mathrm{E}_{\mathrm{u}} \quad=\text { Perkiraan laju erosi yang } \\
& \text { berasal dari areal pertanian } \\
& \text { di dataran tinggi } \\
& \left(\mathrm{m}^{3} \mathrm{ha}^{-1} \text { tahun }^{-1}\right) \\
& \mathrm{E}_{\mathrm{pf}} \quad=\text { Perkiraan laju erosi dari } \\
& \text { lahan sawah } \\
& \left(\mathrm{m}^{3} \mathrm{ha}^{-1} \text { tahun }^{-1}\right) \\
& \mathrm{A}=\text { Luas areal pertanaman padi } \\
& \text { sawah }\left(\mathrm{m}^{2}\right) \\
& \mathrm{CR}=\text { Nilai konversi lahan pada } \\
& 2 \text { dekade berikut, yang } \\
& \text { diasumsikan sebesar 0,3 } \\
& \text { SDR = Sediment Delivery Ratio } \\
& \text { atau Rasio Pengangkutan } \\
& \text { Sedimen, diasumsikan } \\
& \text { sebesar } 0,1 \\
& \mathrm{D}_{\mathrm{c}} \quad=\text { Biaya penyusutan } \\
& \text { bendungan dari setiap unit } \\
& \text { air yang tersimpan } \\
& \left(\mathrm{Rp} \mathrm{m}^{-3} \text { tahun }^{-1}\right. \text { ) } \\
& \mathrm{M}_{\mathrm{c}} \quad \text { = Biaya pemeliharaan } \\
& \text { bendungan dari setiap unit } \\
& \text { air yang tersimpan } \\
& \left(\mathrm{Rp} \mathrm{m}^{-3} \text { tahun }^{-1}\right. \text { ) }
\end{aligned}
$$

3) Fungsi lahan sawah sebagai

\section{pemelihara sumberdaya air}

Lahan sawah merupakan penampung air hujan dan air irigasi. Pengeluaran air dari lahan sawah meliputi aliran permukaan, evapotranspirasi, dan perkolasi. Sebagian dari air perkolasi (diasumsikan sebesar $75 \%$ ) mengalir ke sungai melalui aliran bawah permukaan tanah dan pada akhirnya akan masuk ke bendungan. Sebagian lain dari air perkolasi menambah suplai air tanah. Jumlah air yang menambah suplai air tanah serta aliran permukaan yang menuju ke sungai dan bendungan disebut cadangan air, yang dalam kaitannya dengan lahan sawah merupakan fungsi konservasi air (Agus $d k k, 2003)$. Nilai lahan sawah sebagai pemelihara sumberdaya air dinyatakan dengan rumus :

$$
\begin{aligned}
& \mathrm{WC}_{\text {river }}=(\mathrm{RO}+\mathrm{LSS}) * \mathrm{~S} * \mathrm{~A} * \mathrm{CR} * \\
& \left(D_{c}+M_{c}\right) \\
& \mathrm{WC}_{\text {river }}=\text { Nilai fungsi lahan sawah } \\
& \text { sebagai pemelihara } \\
& \text { sumberdaya air } \\
& \text { (Rp tahun }{ }^{-1} \text { ) } \\
& \text { RO = Aliran permukaan dari } \\
& \text { lahan sawah ke bendungan } \\
& \left(\mathrm{m} \operatorname{tahun}^{-1}\right) \\
& \text { LSS = Aliran bawah permukaan } \\
& \text { dari lahan sawah ke } \\
& \text { bendungan ( } \left.\mathrm{m} \text { tahun }^{-1}\right) \\
& \mathrm{S} \quad=\text { Faktor koreksi aliran } \\
& \text { permukaan dan aliran } \\
& \text { bawah permukaan yang } \\
& \text { mencapai bendungan } \\
& \text { A } \quad=\text { Luas areal pertanaman padi } \\
& \text { sawah }\left(\mathrm{m}^{2}\right)
\end{aligned}
$$

4) Fungsi lahan sawah dalam memperbaiki iklim lokal

Biaya pengganti untuk mitigasi panas didasarkan pada kenyataan bahwa ketika lahan sawah mengalami konversi menjadi areal untuk bangunan dan industri maka akan terjadi peningkatan suhu udara. Hilangnya efek penyejuk yang dihasilkan lahan sawah harus digantikan oleh masyarakat dengan penggunaan sistem pendingin buatan seperti kipas angin dan AC (Agus $d k k, 2004)$. Biaya pengganti untuk mitigasi panas dinyatakan dengan rumus :

$$
\begin{aligned}
& \mathrm{RC}_{\mathrm{HM}}=\left\{\mathrm{F} *\left(\mathrm{M}_{\mathrm{r}}+\mathrm{D}_{\mathrm{r}}\right)+\mathrm{AC}\left(\mathrm{M}_{\mathrm{AC}}+\right.\right. \\
& \left.\left.\mathrm{D}_{\mathrm{AC}}\right)\right\} * \mathrm{~A} * \mathrm{CR} \\
& \text { Keterangan : } \\
& \mathrm{RC}_{\mathrm{HM}}=\text { Nilai fungsi lahan sawah } \\
& \text { untuk mitigasi panas } \\
& \text { (Rp tahun } \left.{ }^{-1}\right) \\
& \mathrm{F} \quad=\text { Jumlah kipas angin pada } \\
& \text { areal penelitian }
\end{aligned}
$$




\begin{tabular}{|c|c|}
\hline $\mathrm{M}_{\mathrm{r}}$ & $\begin{aligned}= & \text { Biaya pemeliharaan kipas } \\
& \text { angin }\left(\mathrm{Rp} \operatorname{tahun}^{-1}\right)\end{aligned}$ \\
\hline Dr & $\begin{aligned}= & \text { Biaya penyusutan kipas } \\
& \text { angin }\left(\mathrm{Rp} \operatorname{tahun}^{-1}\right)\end{aligned}$ \\
\hline $\mathrm{AC}$ & $=\underset{\text { penelitian }}{\text { Jumlah AC pada areal }}$ \\
\hline $\mathrm{M}_{\mathrm{AC}}$ & $\begin{aligned}= & \text { Biaya pemeliharaan AC } \\
& (\text { Rp tahun }\end{aligned}$ \\
\hline $\mathrm{D}_{\mathrm{AC}}$ & $\begin{aligned}= & \text { Biaya penyusutan } \mathrm{AC} \\
& \left(\mathrm{Rp} \operatorname{tahun}^{-1}\right)\end{aligned}$ \\
\hline A & $\begin{aligned}= & \text { Luas areal pertanaman pad } \\
& \text { sawah }\left(\mathrm{m}^{2}\right)\end{aligned}$ \\
\hline $\mathrm{CR}$ & $\begin{aligned}= & \text { Nilai konversi lahan pada } \\
& 2 \text { dekade berikut, yang } \\
& \text { diasumsikan sebesar } 0,3\end{aligned}$ \\
\hline
\end{tabular}

5) Fungsi lahan sawah untuk mengurangi penumpukan sampah organik

Terdapat beberapa cara untuk menghitung nilai lahan sawah dalam fungsinya mengurangi penumpukan sampah organik. Salah satu cara yang dapat digunakan ialah menghitung pengurangan biaya transportasi pembuangan sampah ke tempat pembuangan akhir dengan menggunakan sampah tersebut sebagai pupuk organik pada areal pertanian (Agus $d k k$, 2003). Rumus yang digunakan ialah :

$\mathrm{RC}_{\mathrm{WD}}=\mathrm{O}_{\mathrm{W}} * \mathrm{~T}_{\mathrm{W}} * \mathrm{R}_{\mathrm{OW}} * \mathrm{TC} * \mathrm{~A} * \mathrm{CR}$

Keterangan :

\begin{tabular}{|c|c|}
\hline $\mathrm{RC}_{\mathrm{WD}}$ & $\begin{array}{l}=\text { Nilai fungsi lahan sawah } \\
\text { untuk mengurangi sampah } \\
\text { organik }\end{array}$ \\
\hline $\mathrm{O}_{\mathrm{W}}$ & $\begin{aligned}= & \text { Proporsi persentase sampah } \\
& \text { organik yang dapat } \\
& \text { terdegradasi secara biologi } \\
& \text { dari total sampah perkotaan } \\
& \text { dan domestik (diasumsikan } \\
& \text { sebesar } 50 \% \text { ) }\end{aligned}$ \\
\hline $\mathrm{T}_{\mathrm{W}}$ & $\begin{aligned}= & \text { Total sampah perkotaan } \\
& \text { dan domestik yang } \\
& \text { dihasilkan per tahun } \\
& \left(\text { ton } \text { tahun }^{-1}\right)\end{aligned}$ \\
\hline Row & $\begin{aligned} &= \text { Nilai biodegradasi sampah } \\
& \text { yang dapat digunakan pada } \\
& \text { lahan sawah yang tidak } \\
& \text { menimbulkan dampak } \\
& \text { negatif seperti imobilisasi } \\
& \text { nitrogen }\left(\text { ton } \text { ha }^{-1} \text { tahun }^{-1} \text { ) }\right.\end{aligned}$ \\
\hline TC & $\begin{aligned} &= \text { Perbedaan biaya transpor } \\
& \text { penggunaan sampah pada } \\
& \text { lahan sawah dengan } \\
& \text { pembuangan ke TPA }\end{aligned}$ \\
\hline
\end{tabular}
A
$\mathrm{CR}=$ Nilai konversi lahan pada 2 dekade berikut, yang diasumsikan sebesar 0,3

6) Fungsi lahan sawah sebagai penyedia lapangan pekerjaan

Perhitungan nilai ekonomi lahan sawah sebagai penyedia lapangan pekerjaan menggunakan metode biaya pengganti (Soemarno, 2010) dengan rumus sebagai berikut :

NFTK $=\sum_{\mathrm{i}=1}^{\mathrm{n}}(\mathrm{Ti} \times \mathrm{Wi} \times$ IPi $\times \mathrm{Li})$

Keterangan :

\begin{tabular}{|c|c|}
\hline NFTK & $\begin{aligned}= & \text { Nilai ekonomi lahan } \\
& \text { sawah sebagai penyedia } \\
& \text { lapangan pekerjaan } \\
& \left(\text { Rp tahun }{ }^{-1}\right)\end{aligned}$ \\
\hline $\mathrm{Ti}$ & $\begin{aligned}= & \text { Kebutuhan tenaga kerja } \\
& \text { usahatani padi sawah } \\
& \left(\text { HOK ha }^{-1}\right)\end{aligned}$ \\
\hline Wi & $\begin{aligned}= & \text { Upah tenaga kerja } \\
& \left(\mathrm{Rp} \mathrm{HOK}^{-1}\right)\end{aligned}$ \\
\hline IPi & $\begin{aligned}= & \text { Indeks pertanaman } \\
& \left(\% \text { tahun }^{-1}\right)\end{aligned}$ \\
\hline $\mathrm{Li}$ & $\begin{aligned}= & \text { Luas lahan sawah pada } \\
& \text { unit lahan } \mathrm{i} \text { (ha) }\end{aligned}$ \\
\hline
\end{tabular}

7) Fungsi lahan sawah sebagai habitat flora dan fauna, pemelihara nilai sosial budaya dan daya tarik pedesaan, dan penyangga ketahanan pangan keluarga

Perhitungan nilai ekonomi lahan sawah sebagai habitat flora dan fauna, pemelihara nilai sosial budaya dan daya tarik pedesaan, dan penyangga ketahanan pangan keluarga dilakukan dengan menggunakan Metode Valuasi Kontingensi (Contingent Valuation) dengan pendekatan Willingness to Accept (WTA) yaitu untuk mengetahui seberapa besar petani mau dibayar agar tetap bersedia mengelola dan mempertahankan lahan sawahnya demi menjaga kelestarian fungsi-fungsi tersebut (Rp tahun $\left.{ }^{-1}\right)$ (Sumaryanto $d k k, 2005$ ).

\section{KESIMPULAN}

Pertanian padi sawah di Kabupaten Poso memiliki fungsi-fungsi yang beragam, tidak hanya sebagai penghasil komoditas beras yang 
tangible dan marketable, tetapi juga fungsifungsi lingkungan, sosial, dan budaya yang apabila divaluasi secara ekonomi akan menghasilkan nilai ekonomi yang cukup besar. Konversi lahan sawah ke penggunaan non pertanian merupakan ancaman terhadap keberlanjutan kontribusi multifungsi pertanian bagi kehidupan masyarakat.

\section{REFERENSI}

Agus, F., Wahyunto, R.L. Watung, S.H. Tala'ohu, and Sutono, 2003. Land Use Changes and Their Effects on Environmental Functions of Agriculture. Indonesian Soil Research Institute. Bogor.

Agus, F., R.L. Watung, H. Suganda, S.H. Tala'ohu, Wahyunto, S. Sutono, A. Setiyanto, H. Mayrowani, A.R. Nurmanaf, and M. Kundarto, 2004. Assessment of Environmental Multifunctions of Paddy Farming in Citarum River Basin, West Java, Indonesia. Prosiding Seminar Nasional Multifungsi dan Konversi Lahan Pertanian. Hal. 1 - 28.

Agus, F. dan E. Husen, 2005. Tinjauan Umum Multifungsi Pertanian. Prosiding Multifungsi Pertanian. Hal. $1-16$.

Arifin, B., 2007. Diagnosis Ekonomi Politik Pangan dan Pertanian. Raja Grafindo Persada. Jakarta.

BPS Poso, 2014. Kabupaten Poso dalam Angka 2014. Badan Pusat Statistik Statistik Kabupaten Poso. Poso.

BPS Poso, 2015. Kabupaten Poso dalam Angka 2015. Badan Pusat Statistik Kabupaten Poso. Poso.

Balai Penelitian Tanah, 2006. Konsep Multifungsi untuk Revitalisasi Pertanian. Warta Penelitian dan Pengembangan Pertanian Volume 28 Nomor 25.
Fauzi, A., 2006. Ekonomi Sumberdaya Alam dan Lingkungan : Teori dan Aplikasi. Gramedia Pustaka Utama. Jakarta.

Hanafie, R., 2010. Pengantar Ekonomi Pertanian. Andi Offset. Yogyakarta.

Harini, R., 2012. Kajian Spasial Valuasi Lahan Pertanian Terkonversi dan Dampaknya Terhadap Produksi Pangan di Kabupaten Sleman. Tesis. Program Pasca Sarjana Universitas Gadjah Mada. Yogyakarta.

Irawan, B. Samin, H. Siregar, dan U. Kurnia, 2006. Evaluasi Ekonomi Lahan Pertanian : Pendekatan Nilai Manfaat Multifungsi Lahan Sawah dan Lahan Kering. Jurnal Ilmu Pertanian Indonesia. 11 (3) : $32-41$.

Liu, Y., M. Duan, and Z. Yu, 2013. Agricultural Landscapes and Biodiversity in China. Journal of Agriculture, Ecosystems and Environment. 166 (2013) : $46-54$.

Mukhoriyah, 2012. Kajian Nilai EkologiEkonomi Lahan Sawah dan Kaitannya dengan Rencana Tata Ruang di Kota Depok. Tesis. Program Pasca Sarjana Universitas Indonesia. Jakarta.

Prihtanti, T.M., S. Hardyastuti, S. Hartono, Irham, 2013. Multifungsi Sistem Usahatani Padi Organik dan Anorganik. Jurnal Agrifor. 12 (1) : $11-21$.

Rahardja, P., dan M. Manurung, 2006. Teori Ekonomi Mikro : Suatu Pengantar. Lembaga Penerbit Fakultas Ekonomi Universitas Indonesia. Jakarta.

Soemarno, 2010. Metode Valuasi Ekonomi Sumberdaya Lahan Pertanian. Bahan Kajian Matakuliah Ekonomi Sumberdaya Alam. Program Pasca Sarjana Universitas Brawijaya. Malang.

Sumaryanto, S. Friyatno, dan B. Irawan, 2005. Konversi Lahan Sawah ke Penggunaan Non Pertanian dan Dampak Negatifnya. Prosiding Seminar Nasional Multifungsi Lahan Sawah. Hal. 1 - 18. 
Jurnal ENVIRA Volume 2 Nomor 1 Juni 2017

Sutrisno, J., B. Sanim, A. Saefuddin, S.R.P. Sitorus, 2012. Valuasi Ekonomi Erosi Lahan Pertanian di Sub Daerah Aliran Sungai Keduang Kabupaten Wonogiri. Jurnal SEPA. 8 (2) : $154-161$.

Tobade, E., 2012. Studi Komparatif Usahatani Padi Sawah dan Kakao di Kecamatan Pamona Timur. Skripsi. Fakultas Pertanian Universitas Kristen Tentena. Poso. 
Jurnal ENVIRA Volume 2 Nomor 1 Juni 2017 